\title{
Pemanfaatan Filtrat Abu Sekam Padi untuk Mengurangi Lignin Tongkol Jagung
}

\author{
Utilizing Ash Filtrate of Rice Hull to Reduce Lignin in Corncob \\ I. Hernaman*, B. Ayuningsih, D. Ramdani, dan R. Z. Al-Islami \\ Fakultas Peternakan Universitas Padjadjaran \\ Jl. Raya Bandung-Sumedang KM 21 Jatinangor Sumedang \\ *E-mail: iman hernaman@yahoo.com \\ (Diterima: 24 Oktober 2017; Disetujui: 11 Desember 2017)
}

\begin{abstract}
ABSTRAK
Penelitian bertujuan untuk memanfaatkan filtrat abu sekam padi (FASP) untuk mengurangi lignin dalam tongkol jagung. Penelitian menggunakan rancangan acak lengkap (RAL) menggunakan empat macam perlakuan, yaitu R1 = Tongkol jagung dengan hidrolisis FASP konsentrasi $0,05 \mathrm{~b} / \mathrm{v}$, R2 = Tongkol jagung dengan hidrolisis FASP konsentrasi $0,10 \mathrm{~b} / \mathrm{v}, \mathrm{R} 3$ = Tongkol jagung dengan hidrolisis FASP konsentrasi 0,15 $\mathrm{b} / \mathrm{v}, \mathrm{R} 4=$ Tongkol jagung dengan hidrolisis FASP konsentrasi 0,20 b/v. Setiap perlakuan diulang sebanyak empat kali. Berdasarkan hasil analisis statistik menunjukkan bahwa semakin tinggi abu yang dilarutkan air akan semakin tinggi nilai pH FASP yang diikuti dengan semakin menurunnya kandungan lignin $(\mathrm{P}<0,05)$. Hubungan antara nilai $\mathrm{pH}$ dengan kadar lignin membentuk persamaan regresi $\mathrm{Y}=40,289-3,625 \mathrm{X}$ dengan memiliki hubungan yang kuat dengan nilai $r=0,783$. Perendaman tongkol jagung dengan FASP mampu menurunkan kadar lignin, dengan perlakuan 0,20 b/v menghasilkan persentase lignin yang paling rendah yaitu 7,12\% dan terdapat hubungan yang kuat antara nilai pH FASP dengan kadar lignin.
\end{abstract}

Kata kunci: abu, lignin, sekam padi, tongkol jagung

\section{ABSTRACT}

This research aimed to utilize ash filtrate of rice hull (AFRH) to reduce a lignin content in corncob. Completely randomized design (RAL) was used in this experiment with 4 treatments: $R 1=$ corncob with $0,05 \mathrm{~b} / \mathrm{v}$ concentration of AFRH hydrolysis, $R 2=$ corncob with $0,10 \mathrm{~b} / \mathrm{v}$ concentration of AFRH hydrolysis, $R 3=$ corncob with $0,15 \mathrm{~b} / \mathrm{v}$ concentration of AFRH hydrolysis, $R 4=$ corncob with $0,20 \mathrm{~b} / \mathrm{v}$ concentration of AFRH hydrolysis. Each treatment was repeated 4 times. Statistical results showed that the higher ash which was dissolved by water would be the greater $\mathrm{pH}$ value of $\mathrm{pH}$ and followed by decreased lignin content $(P<0.05)$. The relationship between $\mathrm{pH}$ and lignin content formed regression equation $Y=40,289-3,625 \mathrm{X}$ and had a strong relationship with $r=0.783$. Soaking corncob with AFRH reduced lignin content with 0.20 $b / v$ resulted in the lowest percentage of lignin (7.12\%). There was a significant relationship between $p H$ and AFRH on lignin content.

Keywords: ash, corncob, corncob, rice hull

\section{PENDAHULUAN}

Kebutuhan biji jagung selalu meningkat seiring dengan tingginya permintaan komoditas tersebut untuk budidaya ternak unggas, tercatat produksi jagung nasional pada tahun 2015 adalah 19.612.435 juta ton (BPS, 2017). Peningkatan produksi jagung pipil berakibat pada melimpahnya hasil samping berupa tongkol jagung. Tongkol jagung merupakan bagian dari buah jagung setelah biji dipipil (Tangendjaja dan Wina, 2006). Potensinya sebesar $20 \%$ dari total produksi hasil samping tanaman jagung (McCutcheon dan Samples, 2002).

Tongkol jagung memiliki kandungan protein yang rendah $(2,8 \%)$ dengan kadar lignin yang tinggi (15,8\%) (Shofiyanto, 2008). Lignin menyebabkan selulosa menjadi tidak tersedia untuk difermentasi 
di dalam rumen, karena secara alami lignin mengikat kuat selulosa, sedangkan selulosa dibutuhkan oleh mikroba rumen sebagai sumber energi, akibatnya kecernaannya menjadi rendah. Yulistiani (2010) menyatakan bahwa kecernaan tongkol jagung kurang dari $50 \%$, sehingga sebelum diberikan pada ternak ruminansia sebaiknya tongkol jagung dilakukan pengolahan.

Tongkol jagung yang diberi perlakuan ammoniasi $3 \%$ dapat dipakai dalam ransum sampai $92 \%$, ketika ransum dasar ini disubstitusi dengan alfalfa $30 \%$ dapat memberikan respon pada kenaikan berat badan domba 2 kali lipat dibanding pakan dasar tongkol jagung yang tidak diberi perlakuan (Brandt and Klopfeinstein, 1986).

Upaya lain yang dapat dilakukan adalah pengolahan dengan memanfaatkan abu sekam padi sebagai sumber alkali. Abu dapat diperoleh secara murah dan dalam jumlah yang banyak dan biasanya berasal dari sisa pembakaran sekam padi pada industri pembuatan bata merah. Houston (1972) menyatakan bahwa abu sekam padi mengandung oksida alkali yaitu $\mathrm{K} 0,58$ $2,5 \%$; Na 0-1,75 \%; Ca 0,2-1,5\%, dan Mg 0,12-1,96 \% bahan kering abu sekam. Berdasarkan hasil penelitian menunjukkan bahwa penggunaan larutan abu sekam pada konsentrasi $30 \%$ mampu meningkatkan kecernaan isi rumen (Wijaya, 2007) dan menurunkan lignin Sorghum plumosum var. Timorense sebesar 20,28\% (Dato, 1998). Pada dasarnya teknik hidrolisis FASP ini sederhana, sehingga mudah diterapkan di pedesaan (Sutrisno et al., 1986). Penelitian bertujuan untuk memanfaatkan filtrat abu sekam padi (FASP) untuk mengurangi lignin dalam tongkol jagung.

\section{METODE}

Pembuatan filtrate abu sekam padi mengikuti metode Sutrisno et al. (1986) yang dimodifikasi. Abu sekam padi dilarutkan ke dalam air 1 liter dalam wadah plastik masing-masing sebanyak 50,100, 150, dan $200 \mathrm{~g}$ untuk setiap perlakuan. Hasil pelarutan tersebut menghasilkan konsentrasi filtrat yang ditentukan dengan satuan ukuran berat/ volume $(\mathrm{b} / \mathrm{v})$. Kemudian campuran diaduk hingga merata. Selama 24 jam dilakukan proses pengendapan hingga airnya menjadi bening yang kemudian disaring dengan kain blaco. Air yang tersaring disebut filtrate abu sekam padi (FASP) dan diukur nilai $\mathrm{pH}$ dengan menggunakan $\mathrm{pH}$ meter. Masingmasing sebanyak $250 \mathrm{~mL}$ (perbandingan $1: 1 \mathrm{~b} / \mathrm{v})$, dipercikkan pada tongkol jagung giling dengan ukuran mesh 20 yang sebelumnya telah dimasukkan di dalam toples plastik sambil diaduk-aduk hingga merata diusahakan agar air dapat meresap ke dalam jaringan tongkol jagung. Selanjutnya substrat dimasukkan ke dalam kantong plastik sambil ditekan-tekan untuk mengurangi rongga udara dan volumenous dalam kantong. Kemudian mulut kantong diikat dengan karet gelang, lalu disimpan dalam ruang pada suhu kamar selama \pm 3 jam. Selesai pemeraman, substrat dikeringkan menggunakan sinar matahari sampai kering jemur. Tongkol jagung olahan yang sudah kering dihaluskan menggunakan hammer mill dan siap dianalisis kandungan lignin (Van Soest, 1965). Adapun percobaan yang dilakukan pada tahap ini adalah:

$\mathrm{R} 1=$ Tongkol jagung dengan pengolahan filtrat abu jerami padi (FASP) $0,05 \mathrm{~b} / \mathrm{v}$

$\mathrm{R} 2=$ Tongkol jagung dengan pengolahan filtrat abu sekam padi (FASP) $0,10 \mathrm{~b} / \mathrm{v}$

R3= Tongkol jagung dengan pengolahan filtrat abu sekam padi (FASP) $0,15 \mathrm{~b} / \mathrm{v}$

$\mathrm{R} 4=$ Tongkol jagung dengan pengolahan filtrat abu sekam padi (FASP) $0,20 \mathrm{~b} / \mathrm{v}$

Data yang terkumpul selanjutnya dilakukan uji Duncan dan untuk melihat hubungan antara $\mathrm{pH}$ filtrat dan kadar lignin dilakukan analisis regresi (Steel and Torrie, 1993). 
Tabel 1. Pengaruh Perlakuan terhadap nilai pH dan kadar lignin.

\begin{tabular}{lcccc}
\hline Peubah & R1 & R2 & R3 & R4 \\
\hline pH Filtrat & $8,68^{\mathrm{a}} \pm 0,08$ & $8,72^{\mathrm{ab}} \pm 0,13$ & $8,86^{\mathrm{b}} \pm 0,11$ & $9,12^{\mathrm{c}} \pm 0,13$ \\
Lignin (\%) & $9,61^{\mathrm{d}} \pm 0,30$ & $8,37^{\mathrm{c}} \pm 0,19$ & $7,79^{\mathrm{b}} \pm 0,10$ & $7,12^{\mathrm{a}} \pm 0,11$ \\
\hline
\end{tabular}

Keterangan: Superkrip yang berbeda ke arah baris menunjukkan berbeda nyata $(\mathrm{P}<0,05)$

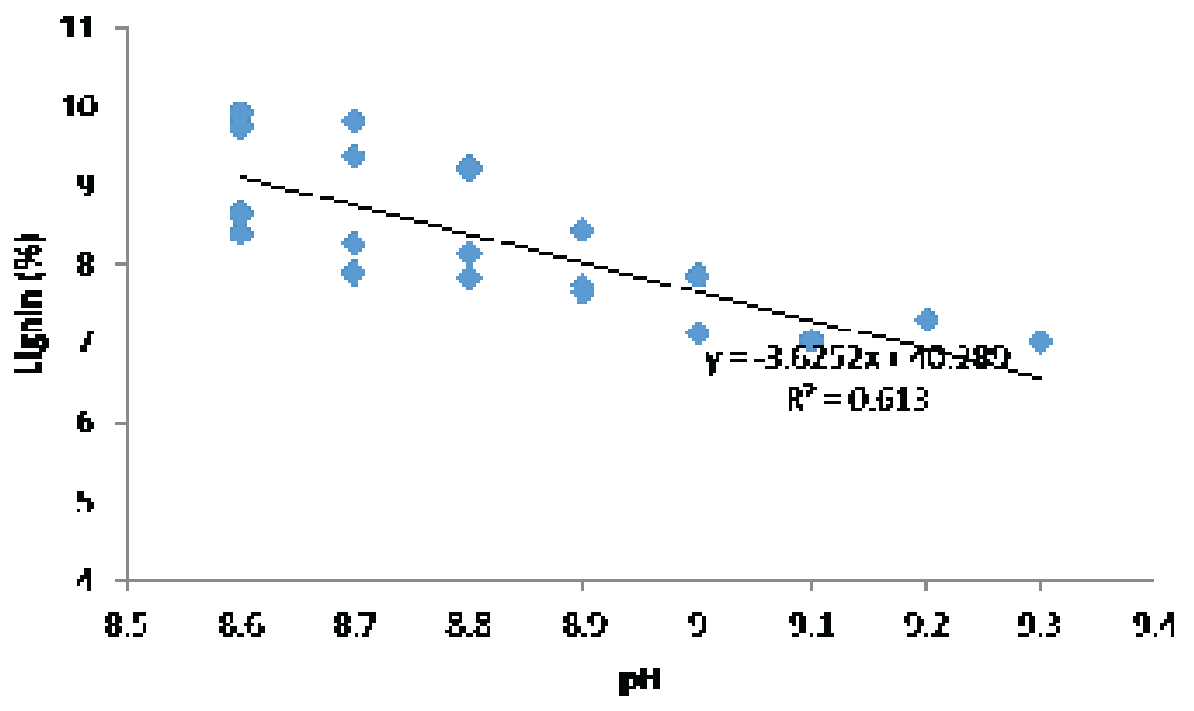

Gambar 1. Hubungan antara Nilai pH dengan Lignin.

\section{HASIL DAN PEMBAHASAN}

Hasil penelitian pengaruh perlakuan terhadap nilai $\mathrm{pH}$ FASP dan lignin substrat disajikan pada Tabel 1. Pada tabel tersebut menggambarkan bahwa nilai $\mathrm{pH}$ mengalami peningkatan sejalan dengan meningkatnya kadar abu yang dilarutkan dengan nilai $\mathrm{pH}$ tertinggi diperoleh pada perlakuan 0,20 $\mathrm{b} / \mathrm{v}$. Sementara itu, sebaliknya peningkatan konsentrasi kelarutan abu sekam padi akan menurunkan kadar lignin. Kadar terendah lignin diperoleh pada perlakuan $0,20 \mathrm{~b} / \mathrm{v}$ sebesar 7,12\%.

Abu sekam padi banyak mengandung mineral alkali, dari hasil analisis tercatat mengandung $\mathrm{Ca}, \mathrm{Mg}, \mathrm{Na}$, dan $\mathrm{K}$ (Houston, 1972). Mineral-mineral tersebut bersifat alkali, sehingga bila dilarutkan ke dalam air akan meningkatkan nilai $\mathrm{pH}$. Oleh karena itu, semakin tinggi konsentrasi FASP semakin tinggi nilai $\mathrm{pH}$ yang menunjukan semakin basa larutan tersebut dengan nilai $\mathrm{pH}$ tertinggi sebesar 9,12. Alkali memiliki sifat yang menguntungkan dalam melarutkan lignin dan merenggangkan ikatan lignin dengan selulosa dan hemiselulosa yang sangat dibutuhkan oleh mikroba rumen sebagai sumber energi dan pembentukan volatile fatty acid (VFA) dalam rumen yang diperuntukan sebagai sumber energi utama bagi hewan ruminansia.

Sifat alkali dalam FASP menyebabkan aksi dalam dalam mengolah pakan yang mengandung lignin tinggi, yaitu (1) pemutusan sebagian ikatan ester antara selulosa dan hemiselulosa dengan lignin dan silika, (2) esterifikasi gugus asetil untuk membentuk asam uronat, dan (3) perombakan struktur dinding sel melalui pengembangan jaringan serat yang akhirnya memudahkan penetrasi molekul enzim mikrobia (Komar, 1984). Oleh karena itu, tongkol jagung yang diperam dengan FASP menghasilkan lignin yang rendah. Dato (1998) melaporkan bahwa rumput Sorghum plumosum var. Timorense kering yang diperam dengan FASP pada konsentrasi $15 \%$ dengan lama pemeraman 
1,5 jam mampu menurunkan lignin sebesar 20,28\% (Dato, 1998). Darmawan et al. (2014) penggunaan filtrat abu tandan sawit (FATS) pada konsentrasi 15\% dapat menurunkan kadar lignin dan serat kasar sabut sawit serta peningkatan kecernaan bahan kering dan organik secara signifikan. Secara alamiah lignin sukar didegradasi dan hanya sedikit mikroorganisme yang mampu mendegradasinya (Martina et al., 2015).

Pada Tabel 1 juga mengambarkan adanya hubungan antara nilai pH dengan kadar lignin. Ketika nilai pH meningkat akan diikuti juga dengan penurunan kadar lignin. Untuk lebih jelasnya dapat dilihat pada Gambar 1 . Hubungan antara nilai $\mathrm{pH}$ dengan kadar lignin membentuk persamaan regresi, yaitu $\mathrm{Y}=$ 40,289-3,625X dengan nilai $r=0,783$. Angka pada nilai korelasi (r) menunjukan hubungan yang erat antara $\mathrm{pH}$ dengan lignin (Sugiyono, 2007). Kelarutan lignin, atau kelompok fenol dan bagian dinding sel lain, terutama hemiselulosa akan meningkat ketika diberi perlakuan dengan alkali (Ibrahim, 1982). Hal yang sama dilaporkan pula bahwa alkali pada pengolahan pakan dapat memecahkan lignin, silika dan hemiselulosa (Jackson, 1977). Dengan penurunan kadar lignin akibat dari pengolahan dengan FASP, diharapkan potensi penggunaan tongkol jagung sebagai pakan ternak ruminansia pengganti rumput dapat lebih meningkat lagi.

\section{KESIMPULAN}

Perendaman tongkol jagung dengan FASP mampu menurunkan kadar lignin, dengan perlakuan $0,20 \mathrm{~b} / \mathrm{v}$ menghasilkan persentase lignin yang paling rendah yaitu $7,12 \%$, terdapat hubungan yang kuat antara nilai pH FASP dengan kadar lignin.

\section{UCAPAN TERIMAKASIH}

Penelitian ini didukung oleh dana penelitian PUPT dari Kementerian Riset Teknoogi dan Pendidikan Tinggi dengan No.718/UN6.3.1/PL/2017.

\section{DAFTAR PUSTAKA}

Badan Pusat Statistik, 2017. Produksi Jagung Menurut Provinsi (ton), 1993-2015. https://www.bps.go.id/ linkTableDinamis/view/id/868 diakses [01-12-2017]

Brant, R.T. Jr. and T. J. Klopfenstein, 1986. Evaluation of Alfalfa-Corn Cob Associative Action. I. Interactions between Alfalfa Hay and Ruminal Escape Protein on Growth of Lambs and Steers. J. Anim Sci 63 : 894-901.

Darmawan, A.L. A. Irawan, T. Dhalika, A.R. Tarmidi, Mansyur, A. Budiman, Kurnia A. Kamil and I. Hernaman. 2014. The study on in vitro digestibility of soaked palm oil fiber by filtrated palm oil fruit bunch ash. Majalah Ilmiah Peternakan. Vol. 17 No. 1. p 1-3.

Dato, T.O.D. 1998. Pengolahan Rumput Sorgum plumosum var. timorense Kering dengan Filtrat Abu Sekam Padi terhadap Perubahan Komponen Serat dan Kecernaannya secara in vitro. Bandung: Tesis Program Pascasarjana Universitas Padjadjaran.

Houston, J. 1972. Rice Chemistry and Technology American Association of Cereal Chemistry.

Ibrahim, M.N.M. 1982. Physical, Chemical, Physico-Chemical and Biological Treatments of Crop Residues. 1st Annual Workshop of the AFAR Research Network, 3-7 May, Malaysia. 53-64.

Jackson, M.G. 1977. Review Article: The alkali treatment of straw. Anim. Feed Sci. and Technol. 2 : 105-130.

Komar, A. 1984. Teknologi Pengolahan Jerami sebagai Makanan Ternak. Yayasan Dian Grahita, Bandung. 33.

Martina A., T.M. Linda, D. Zul, N. Veronika, and R. Jelita. 2015. Aktivitas ligninolitik beberapa jamur aphyllophorales dan kemampuannya mendegradasi lignin 
pada lindi hitam. Al-Kauniyah Jurnal Biologi 8 (1) 27-31.

McCutcheon, J. and D. Samples. 2002. Grazing Corn Residues. Extension Fact Sheet Ohio State University Extension. US. ANR 10-02.

Shofiyanto, M.E. 2008. Hidrolisis Tongkol Jagung oleh Bakteri Selulolitik untuk Produksi Bioetanol dalam Kultur Campuran. IPB, Bogor.

Sugiyono. 2007. Metode Penelitian pedidikan pendekatan kuantitatif, kualitatif, dan R\&D. Bandung: Alfabeta.

Sutrisno, C.I., Soelistyono H.S., dan Slamet W. 1986. Potensi Kualitatif dan Kuantitatif Makanan Ternak Ruminansia Besar dalam Kaitannya dengan Efisiensi Usaha Ternak. Dalam: Mukernas III PPSKI, Salatiga.

Tangendjaja, B. dan E. Wina. 2006. Limbah
Tanaman dan Produk Samping Industri Jagung untuk Pakan. Balai Penelitian Ternak, Bogor.

Van Soest, P.J. 1965. Use of detergent in the analysis of fibrous feeds. III. Study of effects of heating and drying on yield of fiber and lignin in forages. J. Assoc. off. Agric. Chem. 48 (4) : 785-790.

Wijaya, K.A. 2007. Pengaruh Penggunaan Larutan Abu Sekam dalam Hidrolisis Isi Rumen Terhadap Kecernaan Secara InVitro. Skripsi. Universitas Brawijaya. Malang.

Yulistiani, D. 2010. Fermentasi Tongkol Jagung (Kecernaan $>50 \%)$ dalam Ransum Komplit Domba Komposit Sumatera dengan Laju Pertumbuhan $>125$ gram/hari. Laporan Penelitian Program Insentif Riset Terapan Balai Penelitian Ternak, Bogor. 